\title{
TERRESTRIAL PROTECTED AREAS AND MANAGED REACHES CONSERVE THREATENED FRESHWATER FISH IN UTTARAKHAND, INDIA
}

\author{
Nishikant Gupta ${ }^{1 *}$, K. Sivakumar ${ }^{2}$, Vinod B. Mathur ${ }^{2}$ and Michael A. \\ Chadwick $^{1}$
}

*Corresponding author: nishikantgupta@live.in

1. Department of Geography, King's College London, UK

2. Wildlife Institute of India, Dehradun, India

\section{ABSTRACT}

Terrestrial protected areas and river reaches managed by local stakeholders can act as management tools for biodiversity conservation. These areas have the potential to safeguard fish species from stressors such as over-fishing, habitat degradation and fragmentation, and pollution. To test this idea, we conducted an evaluation of the potential for managed and unmanaged river reaches, to conserve threatened freshwater fish species. The evaluation involved sampling fish diversity at 62 sites in major rivers in Uttarakhand, India (Kosi, Ramganga and Khoh rivers) both within protected (i.e. sites within Corbett and Rajaji Tiger Reserves and within managed reaches), and unprotected areas (i.e. sites outside tiger reserves and outside managed reaches). In total, 35 fish species were collected from all sites, including two mahseer (Tor) species. Protected areas had larger individual fish when compared to individuals collected outside of protected areas. Among all sites, lower levels of habitat degradation were found inside protected areas. Non -protected sites showed higher impacts to water quality (mean threat score: 4.3/5.0), illegal fishing (4.3/5.0), diversion of water flows (4.5/5.0), clearing of riparian vegetation (3.8/5.0), and sand and boulder mining (4.0/5.0) than in protected sites. This study supports the importance of existing terrestrial protected areas and managed sites for conserving threatened fish and preventing harmful activities.

Key words: Freshwater fish diversity, terrestrial protected areas, anthropogenic stressors, Corbett, Rajaji, Ramganga, Kosi, Khoh

\section{INTRODUCTION}

Terrestrial protected areas are important for biodiversity conservation, genetic resources maintenance and safeguarding ecosystem functions (Keith, 2000; Kingsford \& Nevill, 2005; Mancini et al., 2005; Abell et al., 2007; Roux et al., 2008). For example, the mean body size of fish species was found to be larger in protected than in unprotected areas of Lake Kariba, Zimbabwe (Sanyanga et al., 1995); in the western United States, freshwater preserves have been successfully conserving several fish species, and terrestrial protected areas have also provided conservation benefits to associated species such as the giant freshwater lobster (Astacopsis gouldi) in northern Tasmania (Suski \& Cooke, 2007), and freshwater mussels in the Mississippi river basin (Ricciardi et al., 1998). Additionally, recent studies have highlighted the importance of terrestrial protected areas for freshwater fish species in South Asia (Abraham \& Kelkar, 2012; Sarkar et al., 2013). Freshwater reaches managed by local stakeholders (e.g. community members) have also been shown to provide some benefits to fish species and their associated habitats either through religious beliefs and taboos (Dandekar, 2011), or socio-economic benefits in safeguarding particular fish species (Gupta et al., 2014a).

About 5 per cent of India's geographical area is enclosed within protected areas (Sinha et al., 2009). Legislatively defined terrestrial protected areas perform protective roles for some floral and faunal species (see Post \& Pandav, 2013; Rastogi et al., 2013). Further, aquatic reaches associated with temple pools (see Dandekar, 2011), and reaches managed through local community assistance not only safeguard various threatened 


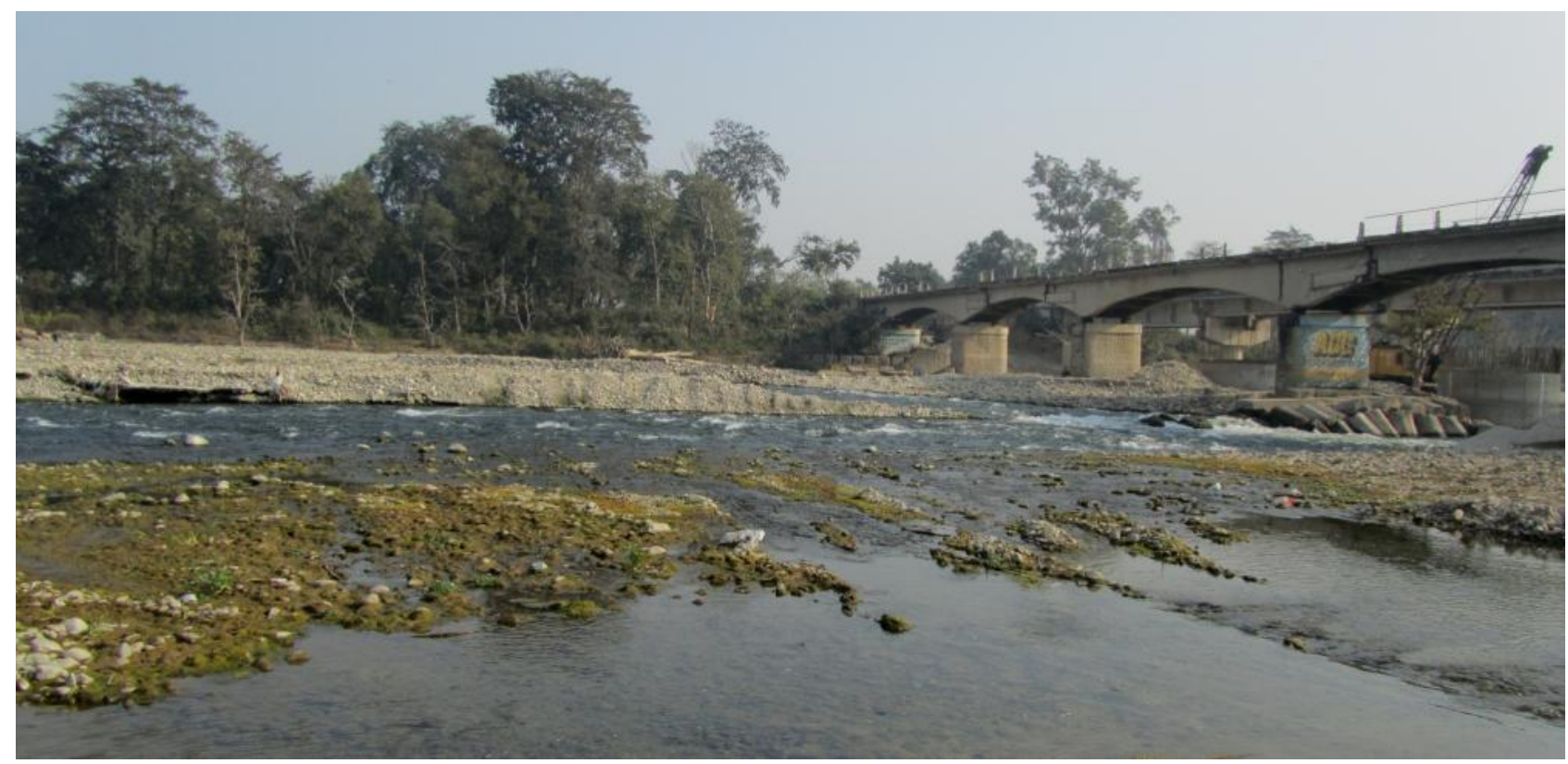

An unprotected site outside Rajaji Tiger Reserve (C) Nishikant Gupta

freshwater fishes but other semi-aquatic and terrestrial species too (see Gupta, 2013). Additionally, river reaches monitored by various angling organizations (i.e., to promote recreational angling of target fish species), are protected by catch-and-release wardens and promote socio-economic opportunities for a range of local stakeholders (see Pinder \& Raghavan, 2013; Gupta et al., 2014a; Pinder et al., 2014).

India is home to major river systems $(n=7)$ which contain numerous freshwater fish species $(\mathrm{n}>900)$ with high levels of endemism (Pinder \& Raghavan, 2013). The fish species here are of importance because they maintain the ecological integrity of freshwater systems (Allen et al., 2010); and also provide a food source for some sections of the society (Gupta et al., 2014a). However, India's increasing population and subsequent urbanization has put pressure on its available water resources (Sarkar \& Bain, 2007) and fish species (Lakra et al., 2010) through habitat fragmentation, habitat loss, flow alterations, and introduction of non-native species (Everard \& Kataria, 2011).

Indian freshwater fishes have not been afforded the support that is directed towards the conservation of mammals, birds and amphibians (Gupta et al., 2014b). For example, freshwater fish conservation and management policies have suffered from setbacks due to jurisdictional issues and oversights, and implementation of top-down approaches (Raghavan et al., 2011); poor enforcement of existing laws (Raghavan et al., 2013); and community-based conservation initiatives often failing to protect river stretches outside their own jurisdiction (Gupta, 2013). Furthermore, no freshwater fish are afforded mention in the Indian Wildlife (Protection) Act,
1972, the highest legal instrument for wildlife conservation in the country (Raghavan et al., 2013).

Past literature has suggested that protected areas have the potential to protect rivers from negative stressors, and improve fish biodiversity (Keith, 2000; Saunders et al., 2002; Sarkar et al., 2008; Abraham \& Kelkar, 2012; Sarkar et al., 2013). In addition, the adequate representation of river systems in protected areas has been suggested to offset various anthropogenic threats (Nel et al., 2009). Some authors have shown high fish densities, and greater sizes of individual fish within protected areas in comparison to sites outside protected areas (Abraham \& Kelkar, 2012; Sarkar et al., 2013). In the Indian Himalayan region alone, there are over 100 terrestrial protected areas, (i.e. National Parks and Wildlife Sanctuaries) (Sarkar et al., 2008). Unfortunately, there is poor representation of river ecosystems within these areas and very few studies have been conducted on the role of existing terrestrial protected areas for conserving river ecosystems. Although often criticized for excluding local village communities and their 'rights to forest', the current terrestrial protected areas network could have the potential to provide benefits to river ecosystems. Additionally, community-conservation initiatives for river ecosystems bordering current terrestrial protected areas could see the inclusion of communities within management initiatives, provide socio-economic benefits to local communities, and potentially assist in protecting river ecosystems from harmful stressors (Gupta, 2013). Therefore, it is necessary to examine terrestrial protected areas in terms of their fish diversity and habitat especially if they encompass perennial rivers within their legislatively defined boundaries. 


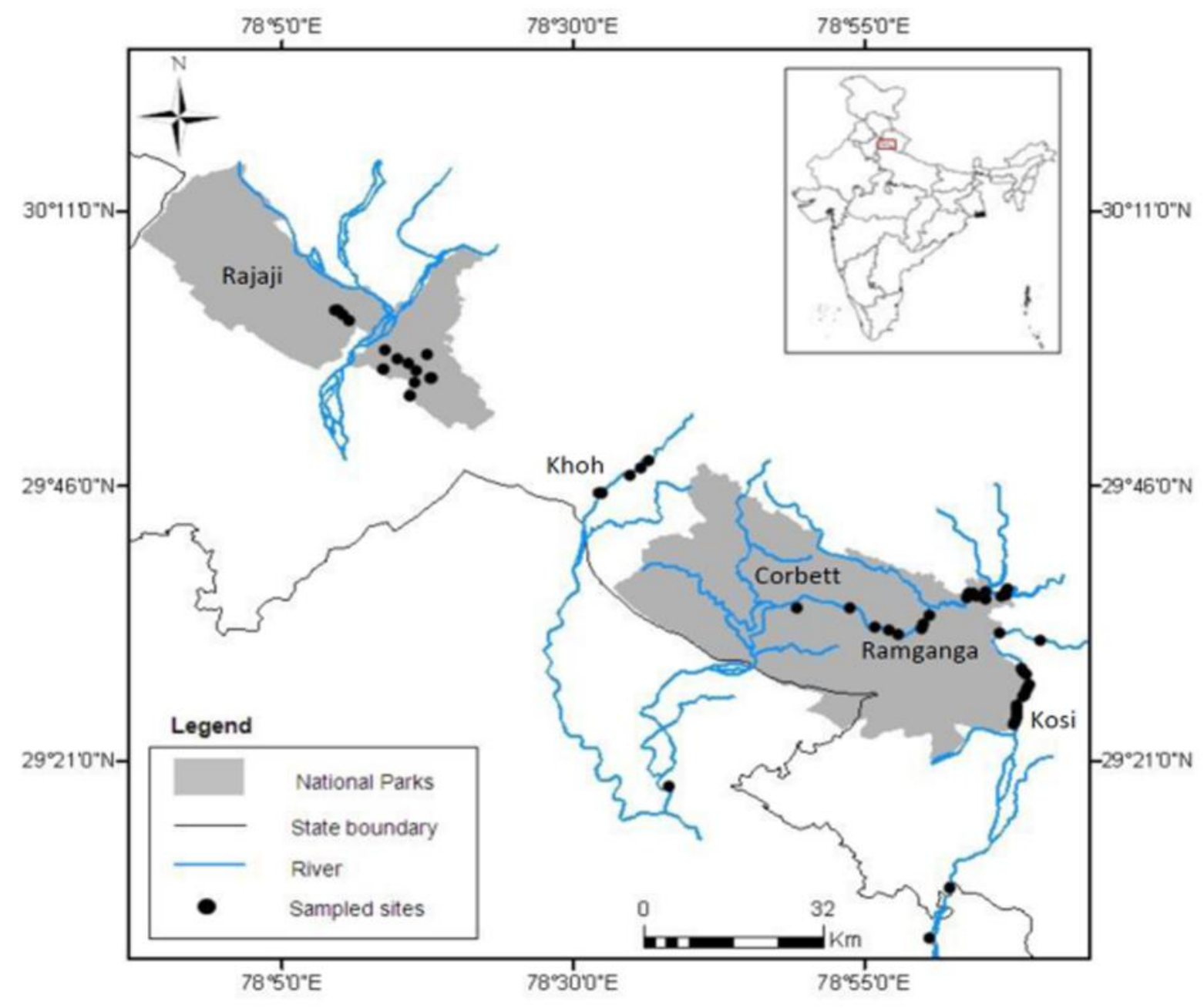

Figure 1: A map of the study area showing the Corbett and Rajaji Tiger Reserves in the north Indian State of Uttarakhand. Also shown are the Kosi, Ramganga and Khoh rivers. The black dots represent the sampled sites (UNPR and PR) (Source: Gupta et al. 2014c)

In view of this rising concern for freshwater fish conservation in India, additional options for their protection need to be investigated to provide vital information and assistance to the ongoing conservation policies of various government agencies. Field studies and documented ecological and socio-economic benefits associated with terrestrial protected areas, temple pools (freshwater reaches safeguarded through religious sentiments and community enforced taboos) and recreational angling pools (prime angling spots on freshwater reaches protected by angling association patrol guards) have been conducted previously by one of the authors (see Gupta et al., 2014a, b, c). We believe that further examining the freshwater bodies and their fish species within terrestrial protected areas and managed reaches, (i.e. temple pools and recreational angling pools under local stakeholder protection) in comparison to unprotected reaches, (i.e. sites outside terrestrial protected areas and outside managed reaches) could offer valuable data for long-term scientific research and assist with freshwater fish conservation.

\section{METHODS}

\section{- Study area}

The Corbett Tiger Reserve is part of the Shivalik mountains in the Bhabar-Terai area of Kumaon and Pauri-Garhwal region of the Indian Himalayas (Joshi et al., 2011). The Rajaji Tiger Reserve is also situated in the Shivalik ranges in the districts of Dehradun, Haridwar and Pauri (Hanna et al., 2001). The Kosi river originates from the Budha Peenath village in the Kausani area of Almora district of Uttarakhand, and has a total length of about $240 \mathrm{~km}$ and a catchment area of $3,420 \mathrm{~km}^{2}$ (Kumar \& Bahadur, 2013). The Ramganga river is an important tributary of the Ganges (Roy \& Sinha, 2007) and originates from the Shivalik Himalayas at Dudhatoli in the district of Chamoli in Uttarakhand (Alam \& Pathak, 2010). The Khoh river is a tributary of the Ramganga, originates from Langur in Dwarikhal and has a catchment basin of over $250 \mathrm{~km}^{2}$ (Bahuguna, 2013). There are many streams within Rajaji Tiger Reserve which originate from the southern slopes of the Shivaliks and converge with the Ganges river (see Figure 1). 


\section{- Sampling approach}

The north-Indian State of Uttarakhand was chosen as the sampling location due to the presence of terrestrial protected areas with perennial freshwater bodies within their boundaries, i.e. Corbett Tiger Reserve (Ramganga river) and Rajaji Tiger Reserve (streams) at similar elevation. Also, managed reaches, i.e. temple pools (on Kosi, Ramganga and Khoh rivers) and recreational angling pools (on Ramganga and Kosi rivers) were present in close proximity to these terrestrial protected areas. The freshwater fish species and observed anthropogenic threats were recorded at sixty-two sites during December 2011 - January 2013 under two main categories: Category I: 'unprotected areas' which consisted of freshwater reaches outside the terrestrial protected areas (Corbett and Rajaji) and outside the managed reaches (temple pools and recreational angling pools) (henceforth UNPR) (see pictures); and Category II: 'protected areas' which consisted of freshwater reaches within the terrestrial protected areas (Corbett and Rajaji) and within the managed reaches (temple pools and recreational angling pools) (henceforth $P R$ ) (see pictures). Furthermore, data relating to captured fish species and observed anthropogenic stressors were also recorded (at both UNPR and PR reaches) individually for terrestrial protected areas, temple pools and recreational angling pools to document the protection provided by these separate management approaches (at both UNPR and PR reaches).

Throughout the study area ecological factors were recorded such as location of terrestrial protected areas and managed areas, environmental gradient and indicator variables (Abraham \& Kelkar, 2012). The river reaches were of roughly the same size, (i.e. width and depth) and found at similar elevations of the Shivalik Himalayan region. An assumption was made that the roughly similar environmental conditions would allow for fair comparisons between resident fish.

Fish sampling was conducted using cast nets, mosquito nets and catch-and-release angling. Each site was sampled twice over the entire field survey. After collection, fish were identified to species using available taxonomic literature (Hamilton, 1822; Talwar \& Jhingran, 1991; Badola, 2001; Jayaram, 2010), their numbers counted, measurements such as total body length $(\mathrm{mm})$ recorded using a measuring scale and then the fish were safely released. Species richness (S), Shannon-Weiner diversity index $(\mathrm{H})$, index of fish diversity and evenness (E) were calculated for the fish species recorded (Sarkar et al., 2013). Observations regarding the various threats present at each sampling site (UNPR + PR) were recorded through direct observations. The threats were grouped into six categories (Abraham \& Kelkar, 2012): sand and boulder mining; dynamite fishing and use of various poisons; overfishing (i.e. occurrence of fishing by local/regional village communities); domestic and urban waste disposal; clearing of riparian vegetation; and water abstraction. Each of these threats were then allocated a score $(\mathrm{o}-5 ; \mathrm{o}=$ no impact, $5=$ most impact $)$ and compared qualitatively between each site.

\section{RESULTS}

In total, 4,989 individual fish were collected from all the sampled sites (UNPR + PR), comprising 35 species representing six families and four orders (Table 1). Family Cyprinidae was dominant representing 25 species. Cyprinids belonging to the genus Barilius ( $B$. barila, B. barna, B. bendelisis, B. schacra and B. vagra) had the highest abundance, $(n=2,245)$. Three 'Near Threatened' (Bagarius bagarius, Labeo pangusia and Tor tor), two 'Vulnerable' (Naziritor chelynoides and Schizothorax richardsonii) and one 'Endangered' ( $T$. putitora) fish species were recorded; all known to have a decreasing population trend (see Table 1; IUCN, 2014).

The UNPR on the Kosi (outside temple pools and angling pools) and Khoh (outside temple pools) had almost similar species richness (S) to the PR (within temple pools and angling pools), i.e. Kosi (UNPR, $n=16: 16$; $P R$, $\mathrm{n}=5: 13$ ) and Khoh (UNPR, $\mathrm{n}=3: 9, \mathrm{PR}, \mathrm{n}=3: 9$ ). Given the dramatic differences in mean abundances among sites, a qualitative approach was used for species richness between UNPR and PR on the Ramganga and streams (Rajaji), i.e. Ramganga: UNPR (outside terrestrial protected areas, outside temple pools, outside angling pools), $n=6$ : 12; PR (within terrestrial protected areas, within temple pools, within angling pools), $n=15$ : 23; and Rajaji: UNPR (streams outside terrestrial protected areas ), $n=4:$ 10; PR (streams within terrestrial protected areas ), $n=10: 19$.

The following results were obtained for the index of fish diversity (mean $\pm \mathrm{SD})$ : Kosi $(\mathrm{UNPR}=3.80 \pm 2.51, \mathrm{PR}=$ $3.33 \pm 2.08$ ); Ramganga (UNPR $=8.25 \pm 2.63, \mathrm{PR}=$ 9.43 \pm 6.29$)$; Khoh (UNPR = 9.00 $\pm 0.00, \mathrm{PR}=9.00 \pm 0.00)$; and Rajaji (UNPR $=5.00 \pm 0.82, \mathrm{PR}=5.40 \pm 5.04$ ). The Shannon-Wiener diversity index $(\mathrm{H})$ was calculated for UNPR and PR on all the sampled sites and gave the following results (mean $\pm \mathrm{SD}$ ): Kosi (UNPR $=2.46 \pm 0.06$, $\mathrm{PR}=1.03 \pm 0.04) ;$ Ramganga $(\mathrm{UNPR}=1.41 \pm 0.17, \mathrm{PR}=$ $1.56 \pm 0.16)$; Khoh $(\mathrm{UNPR}=1.03 \pm 0.02, \mathrm{PR}=1.09 \pm 0.01)$; and Rajaji (UNPR $=1.36 \pm 0.03, \mathrm{PR}=1.62 \pm 0.12$ ). The evenness (E) values were as follows: Kosi (UNPR $=0.85$, $\mathrm{PR}=0.53$ ); Ramganga (UNPR = 0.59, $\mathrm{PR}=0.47$ ); Khoh $(\mathrm{UNPR}=0.58, \mathrm{PR}=0.47)$; and Rajaji $(\mathrm{UNPR}=0.62, \mathrm{PR}=0.53)$. 
Table 1: Fish species $(n=35)$ recorded during the study period. Also shown are their IUCN Red List status, population trend and use. Source: IUCN, 2014

Key: * not evaluated

\begin{tabular}{|c|c|c|c|c|c|}
\hline Order & Family & Species & $\begin{array}{l}\text { Status (IUCN } \\
\text { Red List) }\end{array}$ & $\begin{array}{l}\text { Population } \\
\text { trend }\end{array}$ & Use and trade \\
\hline \multirow[t]{4}{*}{ Cypriniformes } & \multirow[t]{4}{*}{ Nemacheilidae } & $\begin{array}{l}\text { Acanthocobitis } \\
\text { botia }\end{array}$ & Least Concern & Decreasing & Ornamental \\
\hline & & Schistura beavani & Least Concern & Unknown & Ornamental \\
\hline & & Schistura rupecula & Least Concern & Unknown & Ornamental \\
\hline & & Schistura montana & $*$ & $*$ & $*$ \\
\hline Perciformes & Channidae & Channa punctata & Least Concern & Unknown & Food \\
\hline Cypriniformes & Cobitidae & Botia lohachata & $*$ & $*$ & Ornamental \\
\hline \multirow[t]{25}{*}{ Cypriniformes } & \multirow[t]{25}{*}{ Cyprinidae } & $\begin{array}{l}\text { Amblypharyngodon } \\
\text { mola }\end{array}$ & Least Concern & Stable & Food \\
\hline & & Bangana dero & Least Concern & Unknown & Food, game \\
\hline & & Barilius barila & Least Concern & Unknown & $\begin{array}{l}\text { Game, } \\
\text { ornamental }\end{array}$ \\
\hline & & Barilius barna & Least Concern & Stable & Food \\
\hline & & Barilius bendelisis & Least Concern & Stable & Ornamental \\
\hline & & Barilius shacra & Least Concern & Unknown & Ornamental \\
\hline & & Barilius vagra & Least Concern & Unknown & Food \\
\hline & & Cabdio morar & Least Concern & Unknown & Food, ornamental \\
\hline & & Chagunius chagunio & $*$ & $*$ & $*$ \\
\hline & & Crossocheilus latius & Least Concern & Unknown & None recorded \\
\hline & & Garra gotyla & Least Concern & Unknown & Food \\
\hline & & Garra lamta & Least Concern & Unknown & Food \\
\hline & & Gibelion catla & Least Concern & Unknown & Food \\
\hline & & Labeo calbasu & Least Concern & Unknown & Food, game \\
\hline & & Labeo dyocheilus & Least Concern & Unknown & Food \\
\hline & & Labeo pangusia & $\begin{array}{l}\text { Near } \\
\text { Threatened }\end{array}$ & Decreasing & Food \\
\hline & & Pethia conchonius & Least Concern & Unknown & Ornamental \\
\hline & & Pethia ticto & Least Concern & Unknown & Ornamental \\
\hline & & $\begin{array}{l}\text { Naziritor } \\
\text { chelynoides }\end{array}$ & Vulnerable & Decreasing & Food \\
\hline & & Puntius sophore & Least Concern & Unknown & Ornamental \\
\hline & & Raiamas bola & Least Concern & Unknown & Food, game \\
\hline & & $\begin{array}{l}\text { Salmostoma } \\
\text { acinaces }\end{array}$ & Least Concern & Unknown & Food \\
\hline & & $\begin{array}{l}\text { Schizothorax } \\
\text { richardsonii }\end{array}$ & Vulnerable & Decreasing & Game \\
\hline & & Tor putitora & Endangered & Decreasing & Game, food \\
\hline & & Tor tor & $\begin{array}{l}\text { Near } \\
\text { Threatened }\end{array}$ & Decreasing & Food, game \\
\hline Synbranchiformes & Mastacembelidae & $\begin{array}{l}\text { Mastacembelus } \\
\text { armatus }\end{array}$ & Least Concern & Unknown & Food \\
\hline \multirow[t]{3}{*}{ Siluriformes } & \multirow[t]{3}{*}{ Sisoridae } & Bagarius bagarius & $\begin{array}{l}\text { Near } \\
\text { Threatened }\end{array}$ & Decreasing & $\begin{array}{l}\text { Food, } \\
\text { ornamental, } \\
\text { game }\end{array}$ \\
\hline & & $\begin{array}{l}\text { Glyptothorax } \\
\text { pectinopterus }\end{array}$ & Least Concern & Unknown & Food \\
\hline & & $\begin{array}{l}\text { Glyptothorax } \\
\text { telchitta }\end{array}$ & Least Concern & Unknown & Food, ornamental \\
\hline
\end{tabular}


Table 2: Mean total body length $(m m \pm S D)$ of threatened fish species $(n=6)$ recorded from terrestrial protected areas and managed reaches (unprotected and protected sites); and current conservation actions in place for these species. Key: ${ }^{*}$ not recorded; ${ }^{1,5,6}$ Near Threatened; ${ }^{2,3}$ Vulnerable; ${ }^{4}$ Endangered (IUCN, 2014).

\begin{tabular}{|c|c|c|c|c|c|c|}
\hline \multirow[t]{2}{*}{ Sampled area } & \multirow{2}{*}{$\begin{array}{l}\text { Freshwater } \\
\text { body }\end{array}$} & \multirow{2}{*}{$\begin{array}{l}\text { Type of } \\
\text { protection }\end{array}$} & \multirow{2}{*}{$\begin{array}{l}\text { Threatened fish } \\
\text { species recorded }\end{array}$} & \multicolumn{2}{|c|}{ Mean total body length $(\mathrm{mm} \pm \mathrm{SD})$} & \multirow{2}{*}{$\begin{array}{l}\text { Conservation } \\
\text { action in place }\end{array}$} \\
\hline & & & & $\begin{array}{l}\text { Unprotected } \\
\text { site }\end{array}$ & Protected site & \\
\hline \multirow{6}{*}{$\begin{array}{l}\text { Terrestrial } \\
\text { protected area } \\
\text { (Corbett and } \\
\text { Rajaji) }\end{array}$} & \multirow{6}{*}{$\begin{array}{l}\text { Ramganga } \\
\text { (Corbett), } \\
\text { streams } \\
\text { (Rajaji) }\end{array}$} & \multirow[t]{6}{*}{ Legislative } & Labeo pangusia ${ }^{1}$ & $*$ & $206.50 \pm 89.21$ & None \\
\hline & & & $\begin{array}{l}\text { Naziritor } \\
\text { chelynoides }^{2}\end{array}$ & $*$ & $250.05 \pm 25.12$ & None \\
\hline & & & $\begin{array}{l}\text { Schizothorax } \\
\text { richardsonii }\end{array}$ & $*$ & $93.00 \pm 12.55$ & None \\
\hline & & & Tor putitora ${ }^{4}$ & $152.26 \pm 49.01$ & $296.40 \pm 118.84$ & $\begin{array}{l}\text { Habitat } \\
\text { conservation }\end{array}$ \\
\hline & & & Tor tor ${ }^{5}$ & $*$ & $290.00 \pm 56.79$ & None \\
\hline & & & Bagarius bagarius $^{6}$ & $*$ & $657.00 \pm 102.20$ & None \\
\hline \multirow[t]{2}{*}{ Temple pools } & \multirow{2}{*}{$\begin{array}{l}\text { Kosi, } \\
\text { Ramganga, } \\
\text { Khoh }\end{array}$} & \multirow{2}{*}{$\begin{array}{l}\text { Religious } \\
\text { sentiments } \\
\text { and } \\
\text { associated } \\
\text { taboos }\end{array}$} & $\begin{array}{l}\text { Schizothorax } \\
\text { richardsonii }\end{array}$ & $*$ & $104.50 \pm 21.25$ & None \\
\hline & & & Tor putitora & $125.58 \pm 25.69$ & $275.31 \pm 109.56$ & $\begin{array}{l}\text { Habitat } \\
\text { conservation }\end{array}$ \\
\hline \multirow[t]{5}{*}{$\begin{array}{l}\text { Recreational } \\
\text { angling pools }\end{array}$} & \multirow[t]{5}{*}{$\begin{array}{l}\text { Kosi, } \\
\text { Ramganga }\end{array}$} & \multirow[t]{5}{*}{$\begin{array}{l}\text { Local } \\
\text { stakeholders }\end{array}$} & $\begin{array}{l}\text { Naziritor } \\
\text { chelynoides }\end{array}$ & $*$ & $212.55 \pm 35.15$ & None \\
\hline & & & $\begin{array}{l}\text { Schizothorax } \\
\text { richardsonii }\end{array}$ & $*$ & $125.50 \pm 15.57$ & None \\
\hline & & & Tor putitora & $145.79 \pm 58.52$ & $300.58 \pm 99.56$ & $\begin{array}{l}\text { Habitat } \\
\text { conservation }\end{array}$ \\
\hline & & & Tor tor & $*$ & $292.00 \pm 78.99$ & None \\
\hline & & & Bagarius bagarius & $*$ & $755.00 \pm 105.55$ & None \\
\hline
\end{tabular}

Further, to assess the conservation effectiveness of sampled terrestrial protected areas and managed reaches (temple pools and recreational angling pools) for freshwater fish conservation, the mean total body length $(\mathrm{mm} \pm \mathrm{SD})$ of threatened fish species $(\mathrm{n}=6)$, (i.e. Near Threatened, Vulnerable, and Endangered (IUCN, 2014)) recorded was compared between UNPR and PR (see Table 2).

Scores (o = no impact; $5=$ most impact) were assigned to the threats $(n=6)$ at all UNPR and PR sites (see Table 3). At UNPR, water abstraction (mean score; 4.5/5.0); dynamite fishing and use of various poisons (4.3/5.0); overfishing (4.3/5.0); and domestic and urban waste (4.3/5.0) were the main threats recorded. These were closely followed by sand and boulder mining (4.0/5.0) and clearing of riparian vegetation (3.8/5.0). Within PR, domestic and urban waste (1.8/5.0) was the main noted threat (see Table 3).

\section{DISCUSSION}

Overall, our results show higher species richness and presence of greater numbers of threatened fish species within terrestrial protected areas and managed areas (temple pools and angling pools) (see Table 2). The index of fish diversity (mean \pm SD) was comparatively similar within rivers (UNPR+PR), but dissimilar between rivers (Abellan et al., 2007; Sarkar et al., 2013). Similar trends were observed for the Shannon-Weiner diversity index (H) and Evenness (E), and could be due to similar fish diversity, similarity in the relative abundance of fish species, similar geographical distribution, and migratory behaviour of sampled fish species.

Overall, lower threat scores were obtained for sites within terrestrial protected areas and managed reaches in comparison to unprotected sites (see Table 3). The lower threat scores in PR highlights the potential conservation benefits of the studied protected sites (tiger reserves, temple pools and angling associations) for fish species from anthropogenic stressors.

When comparing between the three forms of PR, (i.e. terrestrial protected areas, temple pools and angling pools), terrestrial protected areas recorded six threatened fish species (IUCN, 2014) in comparison to temple pools $(n=2)$ and angling pools $(n=5)$ (see Table 2). Interestingly, of the six recorded threatened species 
Table 3: Assigned scores ( $0=$ no impact; $5=$ most impact) to rivers and their fish species at unprotected (outside terrestrial protected areas, outside temple pools, outside angling pools) and protected (within terrestrial protected areas, within temple pools, within angling pools) sites according to the observed threats $(n=6)$.

\begin{tabular}{|c|c|c|c|c|c|c|}
\hline Threats & $\begin{array}{c}\text { Sand and } \\
\text { boulder mining }\end{array}$ & $\begin{array}{l}\text { Dynamite } \\
\text { fishing and use } \\
\text { of various } \\
\text { poisons }\end{array}$ & Overfishing & $\begin{array}{l}\text { Domestic and } \\
\text { urban waste }\end{array}$ & $\begin{array}{l}\text { Clearing of } \\
\text { riparian } \\
\text { vegetation }\end{array}$ & $\begin{array}{c}\text { Water } \\
\text { abstraction }\end{array}$ \\
\hline $\begin{array}{l}\text { Type of } \\
\text { fishes } \\
\text { affected }\end{array}$ & $\begin{array}{l}\text { Substrate } \\
\text { dwelling }\end{array}$ & All & Food & All & All & All \\
\hline \multicolumn{7}{|c|}{ Kosi } \\
\hline Unprotected & 5 & 5 & 5 & 4 & 4 & 5 \\
\hline Protected & 1 & 1 & 1 & 2 & 3 & 1 \\
\hline \multicolumn{7}{|c|}{ Ramganga } \\
\hline Unprotected & 3 & 5 & 5 & 4 & 4 & 4 \\
\hline Protected & 0 & 0 & 0 & 1 & 0 & 0 \\
\hline \multicolumn{7}{|c|}{ Khoh } \\
\hline Unprotected & 4 & 3 & 3 & 5 & 4 & 5 \\
\hline Protected & 0 & 1 & 1 & 3 & 1 & 2 \\
\hline \multicolumn{7}{|c|}{ Rajaji } \\
\hline Unprotected & 4 & 4 & 4 & 4 & 3 & 4 \\
\hline Protected & 0 & 0 & 0 & 1 & 0 & 0 \\
\hline
\end{tabular}

(IUCN, 2014), only one (T. putitora) was recorded both from the UNPR and PR sites of terrestrial protected areas and managed reaches (see Table 2). This could be attributed to the observed migratory behaviour of this species (Gupta et al., 2014c). Further, terrestrial protected areas scored less for observed anthropogenic threats in comparison to managed reaches (see Table 3). This could be due to the more strictly enforced legislative powers of terrestrial protected areas (N. Gupta, personal observation within the Corbett Tiger Reserve (CTR) and Rajaji Tiger Reserve (RTR)), in comparison to community-driven religious beliefs and associated taboos, or local stakeholder managed species-oriented protective patrolling; and could have influenced the number of threatened species recorded from terrestrial protected areas and managed reaches. The lack of legislative, religious or socio-economic driven protection at UNPR sites could have resulted in increased anthropogenic threats and reduction in fish species richness (see Table 3).

It is also interesting to note the difference in threat scores between the PR (see Table 3). PR on the Ramganga (terrestrial protected areas, temple pools, angling pools) and streams (terrestrial protected areas) were only subjected to domestic and urban waste (mean score: 1.0/5.0). However, PR on the Kosi (temple pools and angling pools) and Khoh (temple pools) were subjected to a minimum of 5 out of 6 observed threats (see Table 3). However, despite these observed benefits there are several ecological and policy oriented concerns and challenges associated with terrestrial protected areas, temple pools and angling pools that need to be addressed (Dudley et al., 2009; Gupta et al., 2014a) before drawing such comparative conclusions (see below). Further, the studied terrestrial protected areas were not set up exclusively to protect the region's freshwater fishes unlike the angling pools, and more extensive research is needed before a comparison can be made.

Despite the examined terrestrial protected areas not encompassing the up- and downstream reaches of the Ramganga (CTR) and the streams (RTR), these terrestrial protected areas do offer some protection to the studied freshwater bodies and their fish species as uncontrolled human access is completely restricted within these areas by enforcement of various legislative measures. Nonetheless, there are ecological and socioeconomic issues associated with terrestrial protected areas which cannot be overlooked in the long run. For example, various tourist roads, temporary bridges and upcoming lodges on river banks within protected areas contribute to habitat degradation (Gupta et al., 2014b; see Table 3). Additionally, semi-structured interviews with local community members living alongside protected areas and forest managers have revealed issues and conflicts regarding rights to forest use (N. Gupta, unpublished data).

There are potential hindrances for the managed reaches too. For example, the diminishing dependence on age-old traditional doctrines could mean that religious beliefs and taboos associated with temple pools could have less relevance in the future, especially in the case of communities living along river banks for whom fish is a 

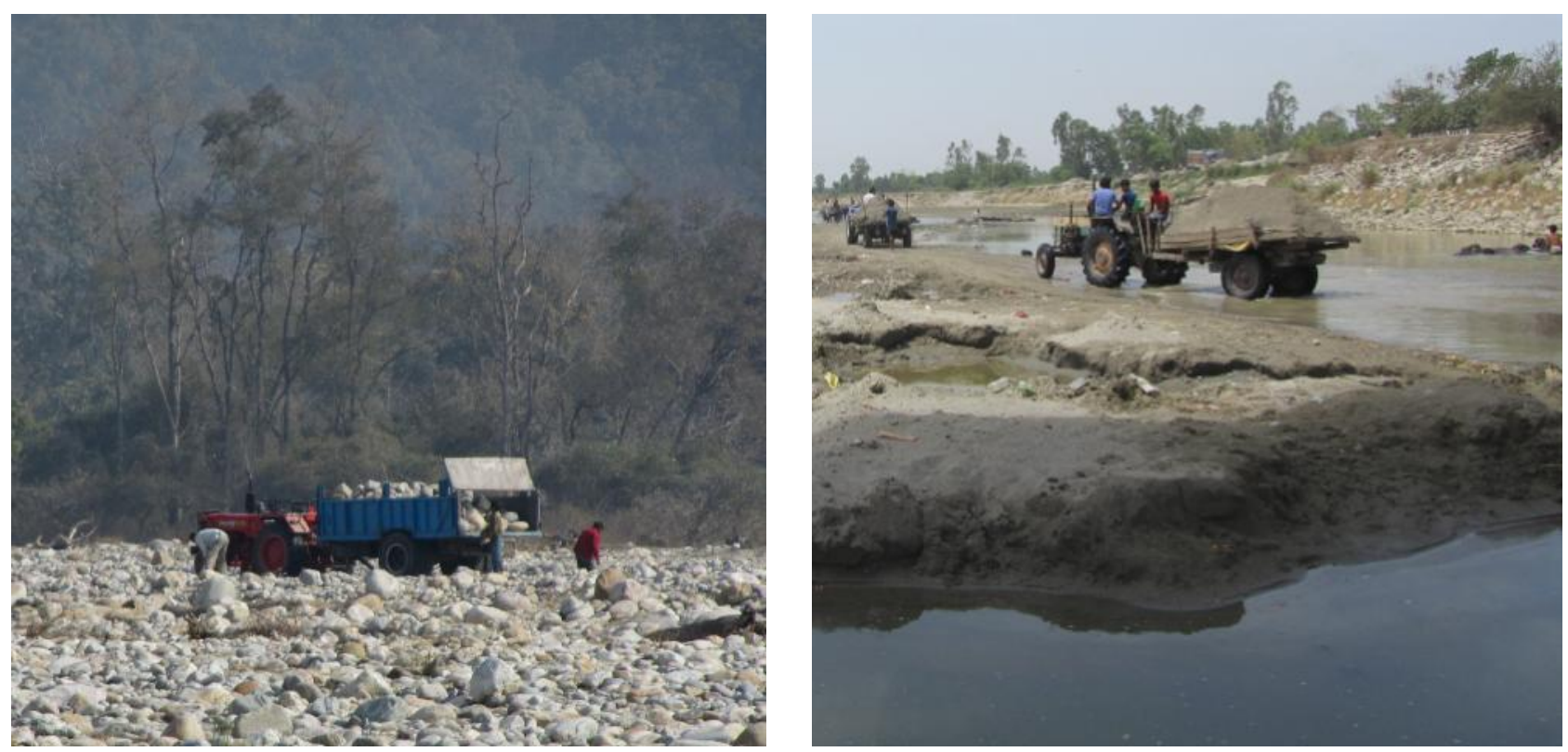

Boulder (left) sand mining (right) in unprotected sites (c) Nishikant Gupta

cheap protein source (Gupta et al., in review). Semistructured interviews conducted with local priests at the studied temple pools have revealed that illegal fishing practices do occur sporadically at these pools during the night (N. Gupta, unpublished data).

Regardless of the socio-economic benefits of angling pools, recreational angling, in general, has been suggested to negatively affect fish communities, food webs and aquatic ecosystems (see Gupta et al., 2014a). Further, previous study in the region has highlighted monetary grievances among some local community members, and conservation concerns among scientists and forest managers regarding recreational angling activity (see Gupta et al., 2014a). We believe that more field based studies need to be conducted to better understand the long-term ecological benefits of angling pools for target fish species.

Nonetheless, it would be unfair to overlook the fact that the studied terrestrial protected areas and managed reaches were successful in providing some protection to the freshwater bodies and the fish species within their boundaries from anthropogenic stressors. For example, of the 21 recorded food fish species of the region (see Table 1), 13 were documented only from PR (terrestrial protected areas and managed sites). These were A. mola, C. morar, C. punctata, G. lamta, G. catla, L. dyocheilus, L. pangusia, N. chelynoides, R. bola, T. tor, B. bagarius, G. pectinopterus and G. telchitta. The remaining fish species $(n=8)$ were found both within UNPR and PR. Among these eight species, the mean length $(\mathrm{mm} \pm \mathrm{SD})$ of locally preferred food fish species (N. Gupta, personal communication with village members living alongside the sampled rivers; $n=5$ ) was significantly higher ( $\mathrm{p}<0.05$; ANOVA) within PR than UNPR sites. For example, B. dero (UNPR: 137.66 \pm 32.64 , PR: 155.80 $\pm 20.00 ; \quad \mathrm{p}=0.0028$ ); B. barna (UNPR: 56.36 \pm 18.48 , PR: 63.67 $\pm 15.56 ; \mathrm{p}=0.0356) ;$ L. calbasu (UNPR: 142.67 \pm 48.79 , PR: $185.38 \pm 64.81 ; \mathrm{p}=0.0001$ ); $S$. acinaces (UNPR: 56.20 $\pm 26.68, \quad$ PR: 73.39 \pm 29.03 ; $\mathrm{p}=0.0005$ ); and T. putitora (UNPR: 152.26 \pm 49.02 , PR: 296.40 $\pm 118.84 ; \mathrm{p}=0.0004$ ).

The potential benefits of the studied terrestrial protected areas and managed sites can be further explained by comparing the mean total body length $(\mathrm{mm} \pm \mathrm{SD})$ of the fish species $(n=4)$ recorded from both UNPR and PR. Although these fish species belong to the Least Concern category (see Table 1), and are not as beneficial as game fish in assessing the conservation effectiveness of sampled terrestrial protected areas and managed reaches for freshwater fish conservation. These fish species are $B$. barna (UNPR: 56.36 \pm 18.48 ; PR: 63.67 \pm 15.56 ; $\mathrm{p}=0.0356$ ), Crossocheilus latius (UNPR: 46.50 \pm 18.78 ; PR: 65.19 $\pm 11.72 ; \mathrm{p}=0.0024$ ), Puntius sophore (UNPR: 57.44 $\pm 23.31 ; \quad$ PR: 74.41 $\pm 17.63 ; \quad \mathrm{p}=0.0097$ ), and Salmostoma acinaces (UNPR: 56.20 \pm 26.68 ; PR: 73.39 $\pm 29.03 ; \mathrm{p}=0.0015)$.

Further, recreational angling, in particular catch-andrelease angling is a rapidly emerging leisure activity in the region (Everard \& Kataria, 2011). However, since the angling ban within protected areas in 2012 (see Pinder \& Raghavan, 2013 for discussion), angling occurs on river reaches outside CTR (Ramganga river) through the issuing of permits by the Uttarakhand Forest Department. Target species are $T$. putitora and $B$. bagarius which attract both domestic and international anglers to the region and bring social and economic benefits to some local communities (Everard \& Kataria, 2011). However, B. bagarius was only recorded from 

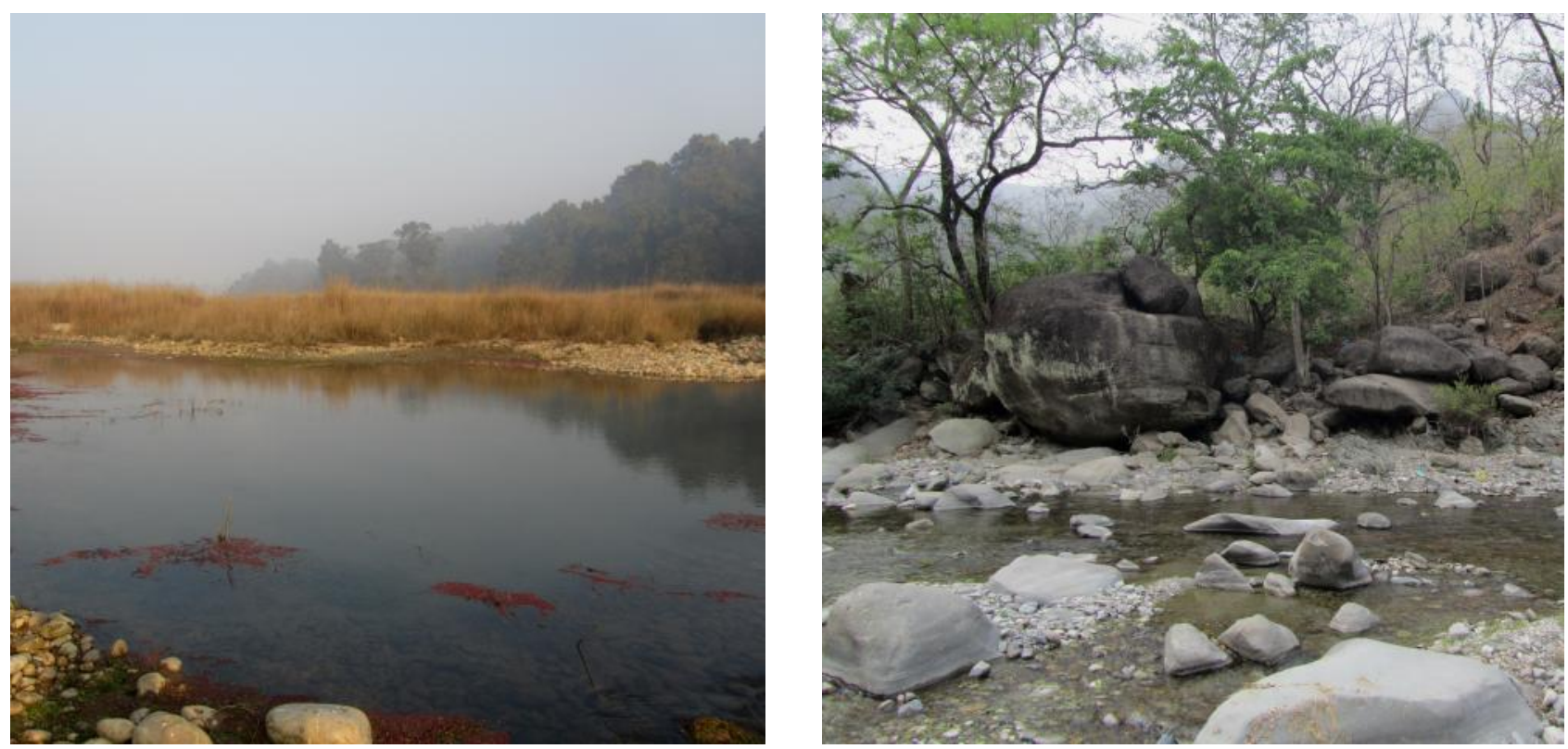

Rajaji Tiger Reserve (left) and temple pools (right) @ Nishikant Gupta

terrestrial protected areas (Ramganga river, CTR), a socio-economic concern for the local stakeholders involved in the angling tourism industry here.

Although T. putitora was documented from UNPR on the Ramganga river where the angling pools are located (see Gupta et al., 2014a), there are several concerns among local stakeholders regarding the anthropogenic threats faced by this species (see Gupta et al., 2014a, c). UNPR on the Ramganga river are subject to rampant dynamite fishing and use of various poisons (mean score: 5.0/5.0) and overfishing (5.0/5.0) (see Table 3). A decline in this remaining angling target species could influence the viability of the current angling tourism in the region, and negatively affect the available socio-economic returns for local stakeholders.

Based on the data obtained during this study, the inclusion of a freshwater body within legislatively defined zones (protected areas), temple pools or angling pools has the potential to offer some protection to the region's freshwater fish species from observed anthropogenic threats. However, the unprotected river reaches outside protected areas; temple pools and angling pools need to be safeguarded from anthropogenic threats to protect locally important food fish species, and angling target species. In view of the observed threats and their intensity of occurrence within unprotected sites, urgent research also needs to be undertaken to ascertain whether the unprotected sites harbour spawning sites or migratory routes of endemic fish species, especially threatened ones for long-term conservation of fish species, and the protection of associated socio-economic benefits.

\section{ACKNOWLEDGEMENTS}

We thank the Directors and DFOs of Corbett and Rajaji Tiger Reserves for granting permission. We thank Dr Rajeev Raghavan for his comments on the manuscript; Samantha Ghosh, Navneet Singh, Vinod Belwal and Sanjeev Paroriya for their help and support. This study was supported by King's College London, UK.

\section{ABOUT THE AUTHORS}

Dr Nishikant Gupta is a freshwater researcher with a focus on investigating novel strategies for river conservation in India. He is especially interested in the threatened mahseer fish species found in Indian rivers. His other interests lie in avian biology, community-based conservation initiatives, recreational angling, flagship species, religion in conservation of species, and protected areas.

Dr K. Sivakumar is a scientist in the Department of Endangered Species Management at the Wildlife Institute of India, Dehradun, India. He has been studying insular, coastal and marine biodiversity for their conservation, particularly birds and mammals of the Southern Ocean and Antarctica. His specializations include ornithology, ichthyology, behavioural ecology, conservation biology and wildlife management.

Dr Vinod B. Mathur is the director of the Wildlife Institute of India, Dehradun, India. He is the Regional Vice-Chair of the IUCN-World Commission on Protected Areas (WCPA-South Asia). He is also the member of United Nations-Intergovernmental Panel on Biodiversity and Ecosystem Services (UN-IPBES) Multidisciplinary 


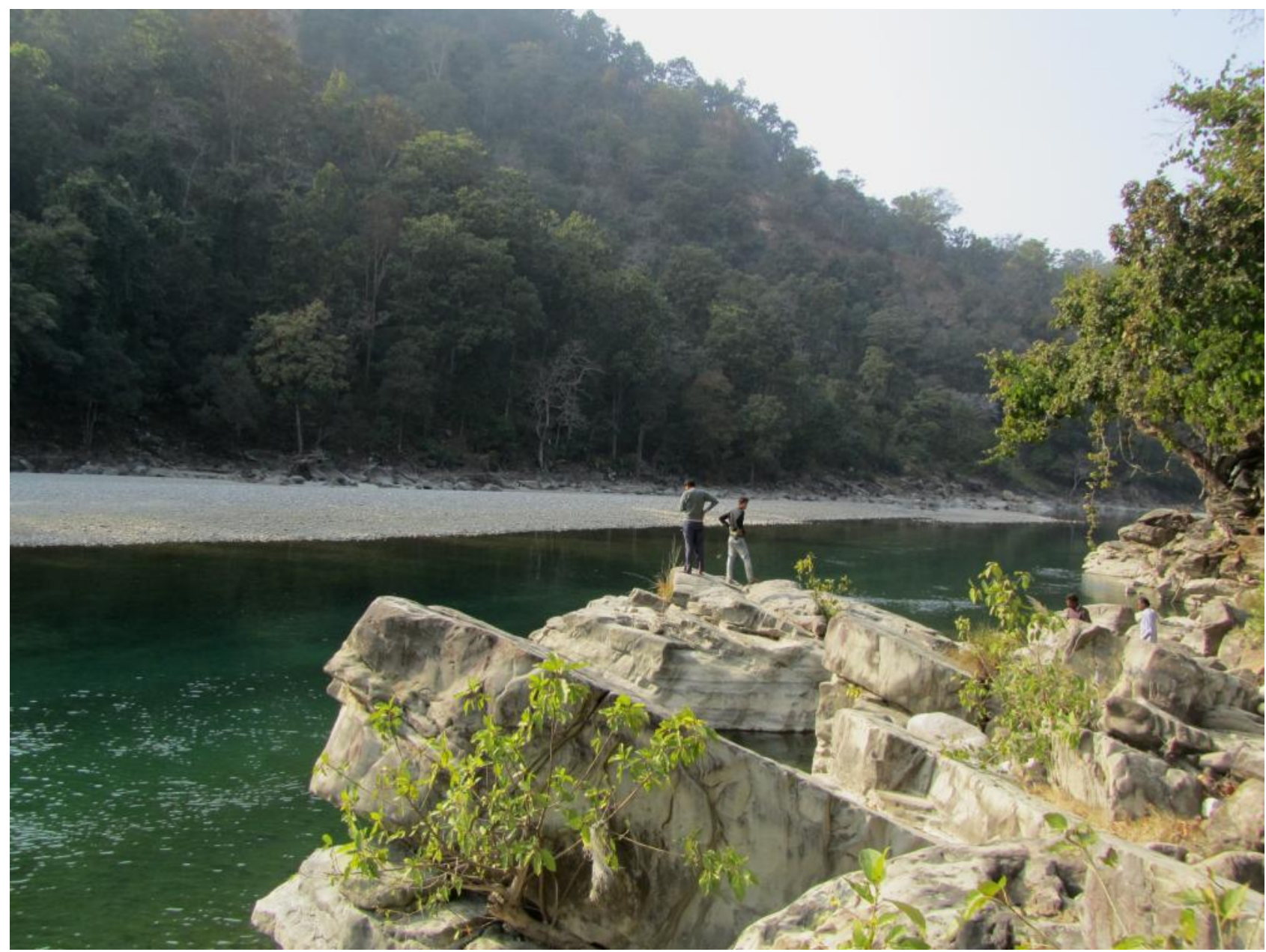

Corbett Tiger Reserve @ Nishikant Gupta

Expert Panel (MEP). His interests include biodiversity conservation, environmental and strategic impact assessment, biodiversity informatics and natural heritage conservation.

Dr Michael A. Chadwick is a lecturer at the Geography Department of King's College London, UK. $\mathrm{He}$ is an aquatic biologist interested in exploring both applied and basic ecological questions. His work focuses on understanding how ecosystem structure and function, specially related to macroinvertebrates, respond to changes in environmental conditions. His research interests are studying the effects of natural and humaninduced ecosystem changes on aquatic organisms; and implications of ecosystem changes on the functioning of aquatic ecosystems.

\section{REFERENCES}

Abell, R., J. Allan and B. Lehner (2007). Unlocking the potential of protected areas for freshwaters. Biological Conservation 134(1): 48-63. DOI:10.1016/ j.biocon.2006.08.017

Abellan, P., D. Sanchez-Fernandez, J. Velasco and A. Millan (2007). Effectiveness of protected area networks in representing freshwater biodiversity: the case of a Mediterranean river basin (south-eastern Spain). Aquatic Conservation: Marine and Freshwater Ecosystems 17: 361 -374. DOI: 10.1002/aqc.778

Abraham, R.K. and N. Kelkar (2012). Do terrestrial protected areas conserve freshwater fish diversity? Results from the Western Ghats of India. Oryx 46(04): 544-553. DOI: http://dx.doi.org/10.1017/S0030605311000937

Alam, M. and J.K. Pathak (2010). Rapid assessment of water quality index of Ramganga river, western Uttar Pradesh (India) using a computer programme. Nature and Science 8(11): 1-8.

Allen, D.J., S. Molur and B.A. Daniel (2010). The status and distribution of freshwater biodiversity in the eastern Himalaya. Cambridge, UK and Gland, Switzerland: IUCN, and Coimbatore, India: Zoo Outreach Organisation.

Badola, S.P. (2001). Ichthyology of Central Himalaya. Srinagar, India: Transmedia Publisher.

Bahuguna, P. (2013). Sex population structure of macrobrachium Assamense peninsularie (Tiwari) (Crustacea, Decapoda, Palaemonidae) in Khoh river, 
Uttarakhand, India. Int.J.Curr.Microbiol.App.Sci 2(10): 382 -390 .

Dandekar, P. (2011). India's community fish sanctuaries protect wild fish and rivers. World Rivers Review 26(4): 17.

Dudley, N., L. Higgins-Zogib and S. Mansourian (2009). The links between protected areas, faiths, and sacred natural sites. Conservation Biology 23(3): 568-577. DOI: 10.1111/ j.1523-1739.2009.01201.x.

Everard, M. and G. Kataria (2011). Recreational angling markets to advance the conservation of a reach of the western Ramganga river, India. Aquatic Conservation: Marine and Freshwater Ecosystems 21(1): 101-108. DOI: 10.1002/aqc.1159

Gupta, N. (2013). Reflections on a successful community conservation programme in Haryana, India. Journal of Development Management 1(3): 117-122.

Gupta, N., P. Nautiyal, A. Borgohain, K. Sivakumar, V.B. Mathur and M.A. Chadwick (2014a). Catch-and-release angling as a management tool for mahseer conservation in India. Oryx. DOI:10.1017/S0030605314000787.

Gupta, N., R. Raghavan, K. Sivakumar and V.B. Mathur (2014b). Freshwater Fish Safe Zones (FFSZs): a prospective conservation strategy for river ecosystem in India. Current Science 107(6): 949-950.

Gupta, N., K. Sivakumar, V.B. Mathur and M.A. Chadwick (2014c). The 'tiger of Indian rivers': stakeholders' perspectives on the golden mahseer as a flagship fish species. Area 46(4): 389-397. DOI: 10.1111/area.12124

Hanna, K. V., M.S. Ravichandran \& S.P.S. Kushwaha (2001). Corridor analysis in Rajaji-Corbett elephant reserve - a remote sensing and GIS approach. Journal of the Indian Society of Remote Sensing 29(1\&2): 41-46. DOI: 10.1007/ BF02989913

Hamilton, F. (1822). An account of the fishes found in the river Ganges and its branches. Edinburgh, UK: Constable and Co.

IUCN (2014). The IUCN Red List of Threatened Species. Version 2014.2. <http://www.iucnredlist.org>accessed on 10 September 2014.

Jayaram, K.C. (2010). The fresh water fishes of Indian region. $2^{\text {nd }}$ Edition, New Delhi, India: Narendra Publication.

Joshi, P.K., K. Yadav and V.S.P. Sinha (2011). Assessing impact of forest landscape dynamics on migratory corridors: a case study of two protected areas in Himalayan foothills. Biodiversity and Conservation 20(14): 3393-3411.

Keith, P. (2000). The part played by protected areas in the conservation of threatened French freshwater fish. Biological Conservation 92: 265-273. DOI:10.1016/S00063207(99)00041-5

Kingsford, R.T. and J. Nevill (2005). Scientists urge expansion of freshwater protected areas. Ecological Management and Restoration 6(3): 161-162. DOI: 10.1111/j.14428903.2005.00232.x

Kumar, A. and Y. Bahadur (2013). Water quality of river Kosi and rajera system at Rampur (India): impact assessment. Journal of Chemistry 2013: 1-4. http:// dx.doi.org/10.1155/2013/618612

Lakra, W.S., U.K. Sarkar, R.S. Kumar, A. Pandey, V.K. Dubey and O.P. Gusain (2010). Fish diversity, habitat ecology and their conservation and management issues of a tropical river in Ganga basin, India. The Environmentalist 30(4): 306-319. DOI: 10.1007/s10669-010-9277-6

Mancini, L., P. Formichetti, A. Anselmo, L. Tancioni, S. Marchini and A. Sorace (2005). Biological quality of running waters in protected areas: the influence of size and land use. Biodiversity and Conservation 14: 351364.DOI: 10.1007/s10531-004-5355-8

Nel, J.L., D.J. Roux, G. Maree, C.J. Kleynhans, J. Moolman, B. Reyers, M. Rouget and R.M. Cowling (2007). Rivers in peril inside and outside protected areas: a systematic approach to conservation assessment of river ecosystems. Diversity and Distributions 13: 341-352. DOI: 10.1111/j.14724642.2007.00308.x

Nel, J.L., B. Reyers, D.J. Roux and R.M. Cowling (2009). Expanding protected areas beyond their terrestrial comfort zone: identifying spatial options for river conservation. Biological Conservation 142(8): 1605-1616. DOI:10.1016/j.biocon.2009.02.031

Pinder, A.C. and R. Raghavan (2013). Conserving the endangered mahseers (Tor spp.) of India: the positive role of recreational fisheries. Current Science 104(11): 14721475.

Pinder A.C., R. Raghavan and J.R. Britton (2014). Efficacy of angler catch data as a population and conservation monitoring tool for the flagship Mahseer fishes (Tor spp.) of Southern India. Aquatic Conservation: Marine and Freshwater Ecosystems DOI: 10.1002/ aqc.2543.

Post, G. and B. Pandav (2013). Comparative evaluation of tiger reserves in India. Biodiversity and Conservation, 22 (12): 2785-2794. DOI: 10.1007/s10531-013-0554-9

Raghavan, R., A. Ali, N. Dahanukar and A. Rosser (2011). Is the Deccan Mahseer, Tor khudree (Sykes 1839) (Pisces: Cyprinidae) fishery in the Western Ghats Hotspot sustainable? A participatory approach to stock assessment. Fisheries Research 110, 29-38. DOI:10.1016/ j.fishres.2011.03.008

Raghavan, R., N. Dahanukar, M.F. Tlusty, A.L. Rhyne, K.K. Kumar, S. Molur and A.M. Rosser (2013). Uncovering an obscure trade: threatened freshwater fishes and the aquarium pet markets. Biological Conservation 164: 158169. DOI:10.1016/j.biocon.2013.04.019

Rastogi, A., G.M. Hickey, R. Badola and A. Hussain (2013). Diverging viewpoints on tiger conservation: a $Q$-method study and survey of conservation professionals in India. Biological Conservation 161:182-192. DOI:10.1016/ j.biocon.2013.03.013

Ricciardi, A., R.J. Neves and J.B. Rasmussen (1998). Impending extinctions of North American freshwater mussels (Unionoida) following the Zebra mussel (Dreissena polymorpha) invasion. Journal of Animal Ecology 67(4): 613-619. DOI: 10.1046/j.1365-2656.1998.00220.x

Roux, D.J., J.L. Nel, P.J. Ashton, A.R. Deacon, F.C. de Moor, D. Hardwick, L. Hill, C.J. Kleynhans, G.A. Maree, J. Moolman and R.J. Scholes (2008). Designing protected areas to conserve riverine biodiversity: lessons from a hypothetical redesign of the Kruger National Park. Biological Conservation 141(1): 100-117. DOI:10.1016/ j.biocon.2007.09.002

Roy, N. and R. Sinha (2007). Understanding confluence dynamics in the alluvial Ganga-Ramganga valley, India: an integrated approach using geomorphology and hydrology. Geomorphology 92: 182-197. DOI:10.1016/ j.geomorph.2006.07.039

Sanyanga, R.A., C. Machenal and N. Kautsky (1995). Abundance and distribution of inshore fish in fished and protected areas in Lake Kariba, Zimbabwe. Hydrobiologia 306: 67-78. DOI: 10.1007/BF00007859 

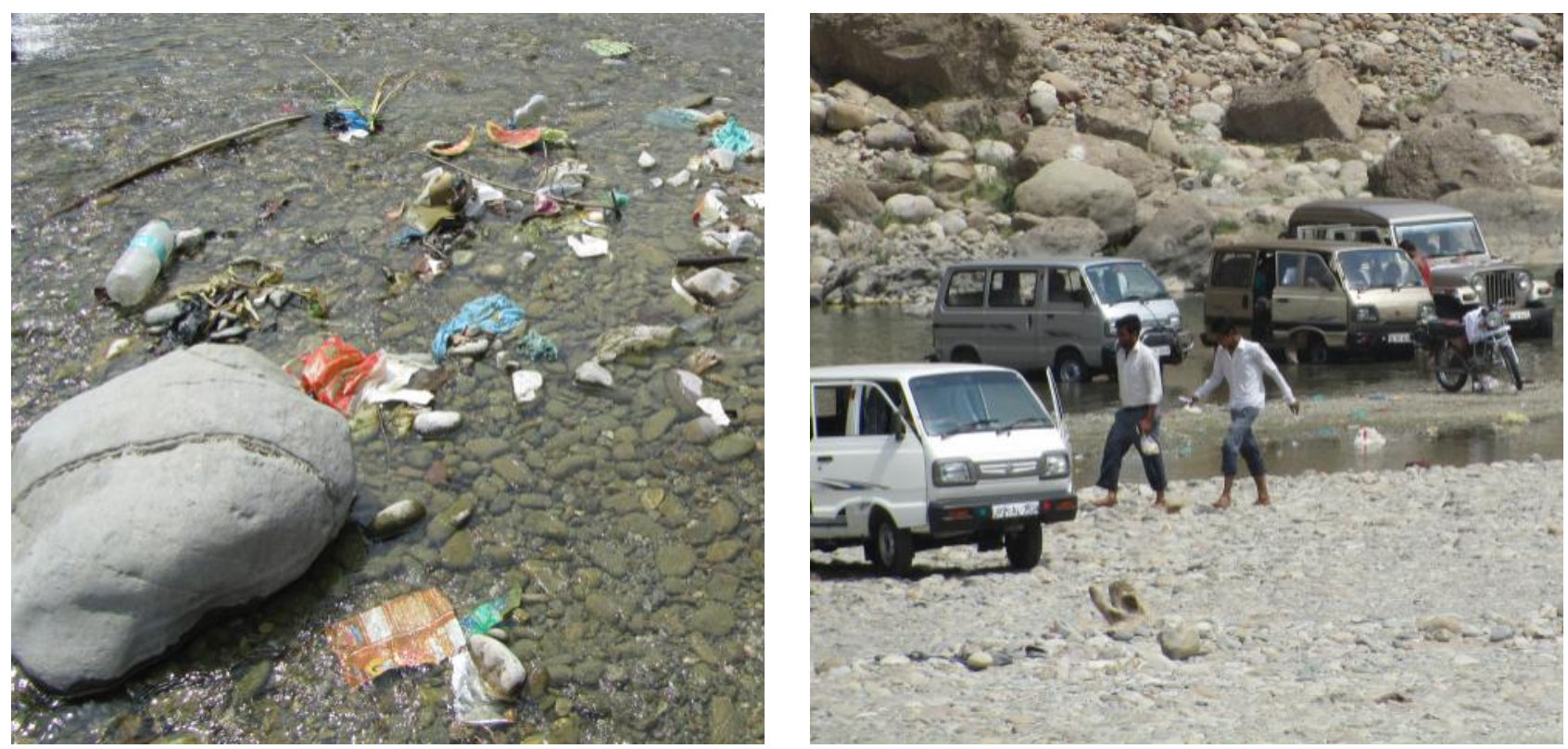

Unprotected sites: domestic and urban waste (left) and outside temple pools (right) @ Nishikant Gupta

Sarkar, U.K. and M.B. Bain (2007). Priority habitats for the conservation of large river fish in the Ganges river basin. Aquatic Conservation: Marine and Freshwater Ecosystems 17: 349-359. DOI: 10.1002/aqc.782

Sarkar, U.K., A.K. Pathak and W.S. Lakra (2008). Conservation of freshwater fish resources of India: new approaches, assessment and challenges. Biodiversity and Conservation 17(10): 2495-2511. DOI: $10.1007 / \mathrm{s} 10531-008-9396-2$

Sarkar, U.K., A.K. Pathak, L.K. Tyagi and S.M. Srivastava (2013). Biodiversity of freshwater fish of a protected river in India: comparison with unprotected Habitat. Int. J. Trop. Biol 61: 161-172.

Saunders, D.L., J.J. Meeuwig and A.C.J. Vincent (2002). Freshwater protected areas: strategies for conservation.
Conservation Biology 16(1): 30-41.DOI: 10.1046/j.15231739.2002.99562.x

Sinha, P.R., V.B. Mathur and A.K. Bhardwaj (2009). Wildlife Protected Area Network in India: A Review. Wildlife Institute of India. 42p.

Suski, C.D. and S.J. Cooke (2007). Conservation of aquatic resources through the use of freshwater protected areas: opportunities and challenges. Biodiversity and Conservation 16(7): 2015-2029. DOI: 10.1007/s10531-006 $-9060-7$

Talwar, P.K. and A.G. Jhingran (1991). Inland fishes of Indian and adjacent countries. Oxford and IBH Publishing Co. Ltd., vol. I \& II.

\section{RESUMEN}

Las áreas terrestres protegidas y los tramos fluviales gestionados por los interesados locales pueden actuar como herramientas de gestión para la conservación de la biodiversidad. Estas áreas pueden proteger las especies de peces contra factores de estrés tales como la sobrepesca, la degradación y fragmentación del hábitat y la contaminación. Para probar este concepto, llevamos a cabo una evaluación sobre el potencial de los tramos fluviales gestionados y no gestionados para conservar las especies amenazadas de peces de agua dulce. La evaluación comprendió el muestreo de una diversidad de peces en 62 sitios en ríos importantes de Uttarakhand, India (los ríos Kosi, Ramganga y Khoh) tanto dentro de áreas protegidas (es decir, sitios dentro de las reservas de tigres Corbett y Rajaji y de tramos gestionados) como no protegidas (es decir, sitios fuera de las reservas de tigres y de tramos gestionados). En total, se recolectaron 35 especies de peces de todos los sitios, incluyendo dos especies de pez carpa (Mahseer). Las áreas protegidas tenían peces más grandes en comparación con los individuos recolectados fuera de las áreas protegidas. Entre todos los sitios, los niveles más bajos de degradación del hábitat se encontraron dentro de las áreas protegidas. Los sitios no protegidos mostraron mayores afectaciones a la calidad del agua (puntuación media de amenaza: 4,3/5,0), pesca ilegal $(4,3 / 5,0)$, desviación de los cursos de agua $(4,5 / 5,0)$, despeje de la vegetación ribereña (3.8/5.0), y extracción de arena y piedra $(4,0 / 5,0)$ que en los sitios protegidos. Este estudio apoya la importancia de la existencia de áreas terrestres protegidas y sitios gestionados para la conservación de peces amenazados y la prevención de actividades perjudiciales. 


\section{RÉSUMÉ}

Les aires protégées terrestres et les tronçons de rivière gérés par les intervenants locaux peuvent servir d'outils de gestion pour la conservation de la biodiversité. Ces zones ont un rôle potentiel dans la protection des poissons face aux facteurs de stress tels la surpêche, la fragmentation et la dégradation de leur habitat, et la pollution. Pour vérifier cette hypothèse dans les cours de rivière gérés et non-gérés, nous avons effectué une évaluation de leur potentiel pour conserver les espèces menacées de poissons d'eau douce. L'évaluation impliquait un échantillonnage de la diversité des poissons sur 62 sites au long de grands fleuves de l'Uttarakhand en Inde (fleuves Kosi, Ramganga et Khoh), soit au sein d'aires protégés (cours d'eau gérés dans les réserves de tigre du Corbett et Rajaji), soit non protégés (cours d'eau non-gérés, hors des réserves). Au total, 35 espèces ont été prélevées, y compris deux espèces de mahseer (tor). Des poissons de plus grande taille se trouvaient dans les aires protégées par rapport aux spécimens récoltés en dehors des aires protégées. Parmi tous les sites, les niveaux les moins élevés de dégradation de l'habitat ont été trouvés à l'intérieur des aires protégées. Les sites non protégés ont révélé des impacts plus élevés sur la qualité de l'eau (note moyenne : 4.3/5.0), la pêche illégale $(4,3 / 5,0)$, le détournement des cours d'eau (4.5/5.0), le défrichement de la végétation riveraine (3.8/5.0) et d'extraction de sable et de galets (4.0/5.0). Cette étude confirme l'importance des aires protégées terrestres et des sites gérés pour la conservation de poissons menacés et la prévention des activités nuisibles. 